\title{
Pungutan Zakat Profesi Pegawai Negeri Sipil (PNS) di Kota Palembang
}

\author{
Umar Hamdan, Ahmad Syathiri, \\ Ahmad Maulana \& Efva Octavina D.G \\ Fakultas Ekonomi Universitas Sriwijaya, Palembang \\ E-mail: umar.hamdan.aj@gmail.com
}

\begin{abstract}
The importance of professional zakat development is also one of the government's efforts to increase the source of state income other than taxes and create synergy between tax and zakat. Along with the development of the Islamic economy which is the solution to the economic development of the Ummah, the professional zakat can be used as a source of funding to be distributed for the welfare of the community. The purpose of this study was to determine the capacity of the ability to pay professional civil service zakat. The method of data collection is done by distributing random questionnaire to 200 civil servants from various agencies that live in the city of Palembang. Data analysis was carried out based on descriptive analysis. The results of the study show that civil servants have a great potential to be collected income zakat.
\end{abstract}

Keywords: Zakah, Zakah Development, Welfare. 


\begin{abstract}
ABSTRAK
Pentingnya pengembangan zakat profesi juga merupakan salah satu upaya pemerintah menambah sumber pendapatan negara selain pajak dan menciptakan sinergisitas antara pajak dan zakat. Seiring dengan perkembangan ekonomi Islam yang menjadi solusi dalam pembangunan ekonomi umat, maka zakat profesi dapat dijadikan sebagai salah satu sumber pendanaan yang akan didistribusikan untuk kesejahteraan masyarakat. Tujuan penelitian ini adalah untuk mengetahui kapasitas kemampuan membayar zakat profesi Pegawai Negeri Sipil di Kota Palembang. Metode pengumpulan data dilakukan dengan penyebaran kuesioner secara random kepada 200 pegawai negeri sipil dari berbagai instansi yang bermukim di kota Palembang. Analisis data dilakukan berdasarkan analisis deskriptif. Hasil penelitian menunjukkan bahwa pegawai negeri sipil memiliki potensi yang besar untuk dipungut zakat penghasilan.
\end{abstract}

Kata Kunci: Zakat, Pengembangan Zakat, Kesejahteraan.

\title{
1. Pendahuluan
}

Wacana mengenai pungutan zakat bagi Pegawai Negeri Sipil (PNS) cukup populer saat ini. Munculnya isu ini bermula dari keinginan pemerintah Republik Indonesia melalui Kementerian Agama mencari sumber dana lain untuk alokasi bagi dunia pendidikan, kesehatan, pemberdayaan ekonomi umat, bahkan dapat digunakan untuk pembangunan infrastruktur yang bertujuan untuk kemaslahatan masyarakat (Republika, 2/2018). Hal ini sejalan dengan ide yang pernah dikemukakan oleh menteri keuangan pada tahun 2017 yang ingin memberlakukan zakat seperti pajak (liputan6.com, 8/2017) dan mendapat dukungan dari Badan Amil Zakat Nasional (Republika.co.id, 8/2017).

Menurut Ombudsman, pungutan wajib zakat bagi Pegawai Negeri Sipil berakibat terjadinya pelanggaran dan maladministrasi karena zakat merupakan ranah privat yang tidak boleh ada ikut campur Negara di dalamnya. Sementara, jika wacana ini dilanjutkan, maka pemerintah harus dapat membuat suatu mekanisme yang membedakan Pegawai Negeri Sipil yang sudah cukup dikenakanan wajib zakat atau tidak, karena masih banyak Pegawai Negeri yang memiliki penghasilan rendah (tempo.co, 2/2018).

Wacana pungutan zakat ini bukan tidak beralasan, mengingat bahwa pemerintah ingin zakat dipungut dan dikelolah secara profesional dan terbangunnya sistem yang memadai. Namun, persoalan pungutan zakat ini terkait dengan syariat Islam yang sudah memiliki aturan yang mengatur tentang syaratsyarat wajib zakat seperti nisab (jumlah harta kena zakat) dan haul (masa satu 
tahun). Persoalan lainnya adalah masih adanya kontroversial mengenai zakat profesi dimasukkan dalam kategori zakat harta yang ditentukan oleh nisab dan haul atau dipersamakan dengan hasil pertanian yang dikeluaarkan zakat ketika panen (Riyadi, 2015). Sebab perkembangan jenis-jenis zakat termasuk zakat profesi merupakan dinamika perkembangan pemikiran tentang zakat setelah masa kenabian (Hayeeharasah et al., 2013).

Pentingnya pengembangan zakat profesi juga merupakan salah satu upaya pemerintah menambah sumber pendapatan negara selain pajak dan menciptakan sinergisitas antara pajak dan zakat (Afriyandi, 2014). Seiring dengan perkembangan ekonomi Islam yang menjadi solusi dalam pembangunan ekonomi umat, maka zakat profesi dapat dijadikan sebagai salah satu sumber pendanaan yang akan didistribusikan untuk kesejahteraan masyarakat (Zen, 2014).

Persoalan lainnya adalah kemampuan individu dalam mencukupi kebutuhan sehari-hari berdasarkan pada penghasilan bulanan. Jika mengacu pada standar kebutuhan hidup layak (KHL) yang diukur menggunakan ukuran upah minimum regional (UMR) plus tunjangan tetap suatu daerah sesuai dengan Peraturan Menteri Ketenagakerjaan Republik Indonesia No. 21 Tahun 2016 Tentang Kebutuhan Hidup Layak, maka kota yang memiliki UMR melebihi UMR provinsi di Sumatera Selatan adalah kota Palembang sebesar Rp. 2.736.000,(tribunnews.com, 12/2017) dibanding UMR Provinsi sebesar Rp. 2.595 .994 (sindonews.com, 11/2017). Kota Palembang juga merupakan kota metropolitan yang memiliki tingkat inflasi (YoY) tahun 2016 sebesar 3,68 persen di atas inflasi provinsi sebesar 3,58 persen (Kumpulan Berita Resmi Statistik Provinsi Sumatera Selatan 2017) yang tentu akan mempengaruhi tingkat pembelian atas komponen kebutuhan hidup layak yang diatur dalam Peraturan Menteri Tenaga Kerja dan Transmigrasi No. 13 Tahun 2012.

Status kota metropolitan yang diikuti pertumbuhanan tempat belanja modern juga akan mempengaruhi gaya hidup seseorang. Gaya hidup perkotaan dapat terjadi karena adanya gesekan budaya sebagai dampak dari heterogenitas masyarakat perkotaan dan terdampak dari sebuah perubahan budaya (Erni, 2016). Gaya hidup akan menentukan pola konsumsi masyarakaat kota dengan berbagai macam latar belakang identitas masyarakat mulai dari status sosial, pendidikan dan penghasilan, sehingga dapat mempengaruhi pola komsumsi masyarakat seperti mulai menggemari untuk berbelanja di pasar modern dan berkunjung ke foodcourt (Mufidah, 2006). Selain itu, fasilitas kebutuhan hidup masyarakat perkotaan semakin mudah didapat seperti kendaraan dan lain sebagainya sehingga mendorong masyarakat untuk memilikinya baik pembelian secara tunai maupun cicilan. Gaya hidup dan pola konsumsi tentu akan menambah beban pengeluaran masyarakat termasuk untuk pengeluaran zakat. Menurut Huda \& Gofur (2012) Saad \& Haniffa (2014) bahwa tingkat ketaatan pembayaran zakat sangat ditentukan oleh sikap seorang muslim dan norma subjektif. 
Zakat pada dasarnya dikeluarkan setelah mempertimbangkan jumlah pendapatan, kebutuhan asasi keluarga yang mencapai batas kecukupan hidup (had al-kifayah) termasuk kebutuhan pendidikan dan kesehatan (Kurnia and Ade Hidayat, 2008: 15). Selain itu, zakat juga harus mempertimbangkan hutang jatuh tempo yang harus segera dibayar (Nurhayati and Wasilah, 2013: 290). Berdasarkan pada latar berlakang di atas, penelitian ini akan membahas tentang bagaimana tingkat kehidupan layak dan kemampuan Pegawai Negeri Sipil di Kota Palembang untuk membayar zakat.

\section{Kajian Pustaka}

\subsection{Formulasi Kebijakan}

Formulasi kebijakan merupakan serangkaian tindakan pemilihan berbagai alternatif kebijakan penyelesaian permasalahan yang dilakukan secara terus menerus dan dilakukan evaluasi (Islamy, 2014: 24; Winarno, 2008:93). Proses formulasi kebijakan dilakukan melalui beberapa tahapan, yaitu (Islamy, 2014: 92): pertama, identifikasi alternatif kebijakan yang dilakukan untuk kepentingan pemecahan permasalahan sehingga mempermudah proses perumusan alternatif. Kedua, mendefinisikan dan merumuskan alternatif kebijakan yang bertujuan untuk memperjelas alternatif-alternatif, sehingga mempermudah pembuat kebijakan dalam menilai dan mempertimbangkan aspek positif dan negatif dari masing-masing alternatif tersebut. Ketiga, menilai alternatif melalui pemberian bobot pada setiap alternatif kebijakan sehingga masing-masing alternatif mempunyai nilai bobot kebaikan dan kekuarangannya. Keempat, memilih alternatif kebijakan untuk diusulkan menjadi kebijakan yang akan dilaksanakan dan memberikan dampak positif bagi masyarakat. Kelima, pengesahan alternatif kebijakan yang merupakan proses kolektif dengan melakukan penyesuaian dan penerimaan secara bersama terhadap prinsip diakui dan diterima.

\subsection{Teori zakat}

Zakat menurut bahasa diartikan sebagai berkah, bersih dan berkembang. (Kurnia and Ade Hidayat, 2008: 2). Definisi zakat secara terminologi merupakan kewajiban bagi muslim untuk mengeluarkan sebagian hartanya berdasarkan pada segi jumlah, waktu pembayaran dan penerimanya yang telah ditentukan dalam syariat Islam. Adanya ketentuan berdasarkan segi jumlah, waktu dan penerima harta ini yang menjadi pembeda dengan infak dan sedekah (Nurhayati and Wasilah, 2013: 284 dan Qardhawi, 1999: 34)

Para ulama fikih sepakat bahwa kewajiban mengeluarkan zakat harus terpenuhinya beberapa syarat (Qardhawi, 1999: 125-155; Kurnia \& Hidayat, 2008: 11): pertama, milik penuh, yaitu muzaki (wajib zakat) memiliki kekuasaan penuh atas harta tersebut seperti sebagai kuasa, penyimpan atau bendahara. Kedua, harta tersebut diprediksi akan bertambah nilainya atau dapat dikembangbiakkan melalui perdagangan. Ketiga, harta tersebut telah mencapai 
nisab (jumlah minimal kena zakat) yang telah ditentukan yaitu setara dengan 85 gram emas. Keempat, harta tersebut telah mencapai haul (genap satu tahun), kecuali hasil pertanian atau sejenisnya. Kelima, tidak terjadi zakat ganda, seperti hasil pertanian yang telah dikeluarkan ketika panen, maka tidak diwajibkan zakat ketika hasil tersebut diperdagangkan. Keenam, harta yang akan dizakatkan merupakan kelebihan dari nafkah kebutuhan pokok dalam keluarga. Ketujuh, terbebas dari hutang.

\subsection{Pandangan Ulama tentang Zakat Profesi atau Penghasilan}

Zakat profesi merupakan pungutan atas penghasilan atau keuntungan dari sebuah profesi seorang muslim yang masuk dalam kajian fikih kontemporer muncul pada aba 20 masehi, karena jenis zakat ini tidak dalam nash Alquran maupun hadis Nabi. Akan tetapi, persoalan zakat profesi ini dikaji menggunakan ilmu Ushul Fiqih yang merujuk pada Alquran dan Hadis melalui perluasan makna lafaznya (Riyadi, 2015).

Penghasilan dalam kajian zakat ini dapat digolongkan dua kategori yaitu penghasilan yang diperoleh dari kegiatan profesional yang membutuhkan keahlian dan penghasilan yang diperoleh dari pihak-pihak pemberi kerja (Marimin \& Fitria, 2015). Semua pendapatan yang diperoleh melalui potensi seseorang seperti upah pekerja, gaji pegawai dan pemasukan pekerja profesional seperti dokter dan lainnya yang tidak berasal dari produksi sesuatu (ternak, pertanian, perdagangan), maka masuk dalam kategori zakat profesi dan penghasilan (Ash-Shawi \& AlMuslih, 2008: 463).

Hukum zakat profesi dan penghasilan menurut Qardawi adalah wajib dan dukung oleh ulama seperti Abdul Wahhab Khallaf, Abu Zahrah, dan organisasi keagamaan seperti Muhamadiyah dan Majlis Ulama Indonesia. Alasan diwajibkan zakat profesi dan penghasilan karena merujuk pada zakat sewa yang diungkapkan oleh Imam Ahmad ibn Hanbal, serta menganalogikan (qiyas) dengan zakat pertanian dan emas dan perak (Riyadi, 2015). Jumlah pungutan zakat profesi dan penghasilan ini terjadi perbedaan di kalangan ulama. Sebagian ulama menyamakan zakat profesi ini dengan zakat pertanian, sehingga zakat dibayarkan ketika menerima penghasilan dengan nisab (jumlah minimal penghasilan) setara dengan $750 \mathrm{~kg}$ beras dan dikeluarkan zakat 5 atau 10 persen. Sedangkan sebagian ulama lainnya menyamakan zakat profesi dengan zakat harta seperti emas dan perak, sehingga seluruh penghasilan harus dihitung untuk masa 1 tahun (haul) dengan nisab 85 gram emas dan dikeluarkan zakat 2,5 persen setiap tahun setelah dikeluarkan biaya kebutuhan pokok (Marimin \& Fitria, 2015; Ash-Shawi \& AlMuslih, 2008: 464).

\section{Metode Penelitian}

Populasi penelitian ini adalah Pegawai Negeri Sipil yang bermukim di kota Palembang. Teknik pengambilan sampel dilakukan menggunakan teknik simple 
random sampling yang memberikan kesempatan kepada semua pegawai negeri sipil beragama Islam untuk dijadikan responden. Teknik pengumpulan data dilakukan melalui penyebaran kuesioner kepada responden yang berstatus sebagai pegawai negeri sipil. Metode analisis data adalah deskriptif analitik.

\section{Hasil Penelitian}

\subsection{Identitas Responden}

Berdasarkan pada hasil pengumpulan kuesioner terhadap responden, didapatkan jumlah responden antara laki-laki dan perempuan cukup seimbang, sehingga responden pada penelitian ini cukup mewakili kedua jenis kelamin tersebut. Usia responden cukup didominasi oleh responden berusia antara 41 sampai dengan 60 dengan tingkat pendidikan sarjana dan golongan tiga.

\subsection{Status Keluarga Responden}

Status keluarga merupakan gambaran keadaan keluarga responden yang dilihat dari aspek status perkawinan, jumlah tanggung keluarga termasuk orang tua, anak ataupun orang lain yang menjadi tanggungannya. Berdasarkan pada hasil penelitian, didapatkan bahwa mayoritas status perkawinan responden adalah berstatus menikah adan memiliki tanggungan keluarga dan mayoritas memiliki anak berusia antara 16-25 tahun. Usia anak antara 16-25 tahun secara umum sedangkan menjalankan pendidikan setingkat menengah atas dan pendidikan tinggi.

\subsection{Kebutuhan Alat Transportasi Responden}

Alat transportasi merupakan alat yang digunakan oleh responden menuju tempat kerja. Alat transportasi ini terbagi dalam dua jenis yaitu kendaraan pribadi yang terdiri dari kendaraan roda dua dan empat serta kendaraan umum. Berdasarkan pada hasil penelitian, menunjukkan bahwa sebagian besar responden tidak menggunakan kendaraan umum sebagai alat transportasi. Hal ini menunjukkan bahwa pegawai negeri yang tinggal di kota Palembang cenderung menggunakan kendaraan pribadi yaitu kendaraan roda dua dan empat.

\subsection{Kepemilikan Tempat Hunian Keluarga}

Tempat hunian merupakan kepemilikan rumah dan lokasi rumah yang didiami oleh responden dalam kesehariannya. Berdasarkan pada hasil penelitian menunjukkan bahwa sebagian besar responden bertempat tinggal di rumah milik sendiri baik didapat melalui pembelian secara tunai atau mengangsur, pembangunan mandiri secara bertahap maupun didapat melalui warisan. Hal ini menunjukkan bahwa ada potensi pengeluaran rutin terkait dengan kepemilikan rumah. Begitupun keadaan pegawai yang bertempat tinggal di rumah sewa yang juga memiliki kewajiban rutin pengeluaran biaya sewa rumah. 


\subsection{Penghasilan Keluarga}

Penghasilan keluarga merupakan gambaran pendapatan seorang responden yang terpisah dengan penghasilan istri atau suami yang terdiri dari penghasilan dari gaji pokok dan tunjangan di samping penghasilan usaha sampingan maupun penghasilan dari suami dan istri. Penghasilan pokok dan tumayoritas responden berkisar antara tiga juta sampai dengan 6 juta rupiah dan memiliki pendapatan di luar gaji serta penghasilan dari istri atau suami.

\subsection{Pengeluaran Keluarga}

Pengeluaran keluarga adalah pengeluaran rutin dalam sebuah keluarga yang terdiri dari pengeluaran pokok konsumsi pangan, listrik, air, komunikasi, pendidikan, transportasi dan kewajiban lainnya seperti cicilan hutang. Mayoritas responden memiliki pengeluaran yang cukup tinggi untuk pengeluaran pokok rutin bulanan untuk kebutuhan rumah tangga dan sebagian besar memiliki kewajiban cicilan hutang dan biaya pendidikan yang cukup besar.

\subsection{Kehidupan Sosial}

Kehidupan sosial merupakan gambaran keterlibatan respoden dalam kehidupan sosial seperti arisan dan rekreasi keluarga sehingga menimbulkan konsekuensi adanya pengeluaran biaya di luar biaya kebutuhan pokok keluarga. Berdasarkan pada hasil penelitian menunjukkan bahwa mayoritas responden menyukai rekreasi dalam kota dengan frekuensi pelaksanaannya tidak terlalu sering. Dengan demikian dapat diartikan bahwa pengeluaran untuk biaya rekreasi tidak terlalu besar dan tidak membebani responden. Adapun keterlibatan responden dengan kegiatan arisan, sebagian besar responden memiliki pengeluaran rutin untuk kegiatan arisan.

\subsection{Persepsi Tentang Zakat}

Persepsi tentang zakat ini merupakan gambaran respon pegawai akan kewajiban mereka dalam menunaikan pembayaran zakat. Mayoritas pegawai menyetujui adanya pemotogan zakat atas gaji pegawai negeri. Dengan demikian dapat diartikan bahwa pegawai negeri sipil menyadari bahwa pembayaran zakat itu wajib bagi seorang muslim.

\section{Pembahasan}

\subsection{Kehidupan Layak Responden}

Berdasarkan pada data responden yang terkumpul, didapatkan bahwa gambaran kehidupan responden di kota Palembang sangat layak. Dilihat dari aspek penghasilan, sebanyak 86,5 persen responden memiliki penghasilan di atas 3,5 juta rupiah. Sebanyak 71 persen suami/istri responden memiliki penghasilan sendiri. Tingkat pendidikan respoden juga sangat baik, yaitu 85,5 persen berpendidikan sarjana dan pascasarjana. Kepemilikan kendaraan baik roda empat 
atau dua menunjukkan bahwa 88 persen responden memiliki kendaraan roda dua dan 72,5 persen memiliki kendaraan roda empat. Mayoritas responden sudah memiliki rumah sendiri. Aktivitas responden juga menunjukkan bahwa mereka juga terlibat dalam kegiatan sosial seperti arisan keluarga, kantor dan lain sebagainya. Mayoritas responden juga mampu menikmati hiburan seperti rekreasi keluarga. Pengeluaran responden juga cukup tinggi dengan rata-rata di atas 4 juta rupiah per bulan serta sebanyak 71 persen responden memiliki cicilan hutang. Dengan demikian dapat dikatakan bahwa mayoritas pendapatan dan pengeluaran responden seimbang.

\subsection{Kapasitas Membayar Zakat}

Zakat profesi merupakan zakat atas hasil profesi yang bersumber dari pendapatan atau penghasilan orang-orang masa kini seperti pegawai, konsultan, dokter dan notaris. Zakat profesi dikategorikan sebagai jenis harta wajib zakat berdasarkan pada kias (analogi) atau kemiripan (syabhah) terhadap karakteristik harta zakat pertanian atau harta simpanan bersifat tahunan (www.dhompetdhuafa.org). Untuk zakat pertanian, nisab ditentukan sebesar 522 $\mathrm{kg}$ dengan kadar zakat sebesar 2,5 persen. Sedangkan untuk nisab zakat harta simpanan setara dengan 85 gram emas yang disimpan selama periode satu tahun. Berdasarkan pada Fatwa MUI Nomor 3 Tahun 2003, zakat penghasilan dikeluarkan jika sudah memenuhi nisab dalam satu tahun senilai 85 gram emas dengan kadar zakat sebesar 2,5 persen.

Kemampuan membayar zakat oleh pegawai negeri sipil jika mengacu pada zakat pertanian adalah pegawai yang memiliki penghasilan minimal setara dengan $522 \mathrm{~kg}$ hasil pertanian. Jika zakat pertanian distandarkan dengan beras, maka harga rata-rata beras Rp. 10.000, maka gaji pokok dan tunjangan kena zakat setiap bulannya adalah setara dengan Rp5.220.000,-. Berdasarkan pada data responden, responden yang memiliki penghasilan di bawah 3,5 juta sebanyak 13,5 persen, penghasilan di antara 3,6-5,9 juta sebanyak 53,5 persen dan penghasilan di atas 5,9 juta sebanyak 33 persen. Dengan demikian dapat diketahui sebanyak 13,5 persen responden pegawai negeri tidak wajib zakat.

Untuk perhitungan zakat yang mengacu pada standar zakat simpanan emas, maka ada dua model perhitungan zakat yaitu zakat dipungut secara langsung tanpa mempertimbangkan pengeluaran kebutuhan pokok yang dapat dipungut dalam setian bulan dan zakat dipungut setelah dikurangi pengeluaran kebutuhan pokok yang baiknya dilakukan pada akhir periode satu tahun. Jika diasumsikan harga emas per gram adalah Rp550.000,00, maka nisab emas 85 gram adalah Rp550.000,00 x 85 gram = Rp46.750.000,00 untuk masa haul (periode) satu tahun atau Rp3.895.833,00 per bulan. Berdasarkan pada data responden, jika menggunakan metode pungutan langsung ini, maka 13,5 persen pegawai negeri sipil tidak kena wajib zakat. 
Untuk pungutan zakat yang mempertimbangkan pengeluaran kebutuhan pokok, maka perlu adanya pertimbangan atas penghasilan total dari berbagai sumber dan dikurangi dengan pengeluaran kebutuhan pokok keluarga selama satu tahun. Berikut ini beberapa perhitungan wajib atau tidak wajib zakat bagi Pegawai Negeri:

Tabel 1.1

\section{Perhitungan Zakat Berdasarkan Data Responden (dalam Rupiah)}

\begin{tabular}{|c|c|c|c|}
\hline Skenario & Sumber Penghasilan Bulanan & Jumlah Minimal & Keterangan \\
\hline 1 & $\begin{array}{l}\text { Pendapatan: } \\
\text { - } \quad \text { Gaji Pokok dan Tunjangan } \\
\text { - } \quad \text { Istri/Suami } \\
\text { Total Pendapatan } \\
\text { Pengeluaran kebutuhan pokok } \\
\text { - } \quad \text { Konsumsi } \\
\text { - } \quad \text { Listrik, Air dan Telpon } \\
\text { - } \quad \text { Transportasi } \\
\text { - } \quad \text { Pendidikan } \\
\text { Total Pengeluaran } \\
\text { Penghasilan Bersih } \\
\end{array}$ & $\begin{array}{l}-3.500 \times 12=42.000 \\
-5.000 \times 12=60.000 \\
=102.000 \\
-3.000 \times 12=36.000 \\
-1.000 \times 12=12.000 \\
-1.000 \times 12=12.000 \\
-1.000 \times 12=12.000 \\
=72.000 \\
=102.000-72.000=30.000\end{array}$ & $\begin{array}{l}\text { Penghasilan } \\
\text { bersih di bawah } \\
\text { nisab emas, } \\
\text { maka tidak } \\
\text { wajib zakat } \\
\text { dengan asumsi } \\
\text { semua } \\
\text { pengeluaran } \\
\text { adalah } \\
\text { kebutuhan } \\
\text { pokok }\end{array}$ \\
\hline 2 & $\begin{array}{l}\text { Pendapatan: } \\
\text { - } \quad \text { Gaji Pokok dan Tunjangan } \\
\text { - } \quad \text { Istri/Suami } \\
\text { Total Pendapatan } \\
\text { Pengeluaran kebutuhan pokok } \\
\text { - } \quad \text { Konsumsi } \\
\text { - } \quad \text { Listrik, Air dan Telpon } \\
\text { - } \quad \text { Transportasi } \\
\text { - } \quad \text { Pendidikan } \\
\text { Total Pengeluaran } \\
\text { Penghasilan Bersih }\end{array}$ & $\begin{array}{l}-5.900 \times 12=70.800 \\
-5.000 \times 12=60.000 \\
=130.000 \\
-3.000 \times 12=36.000 \\
-1.000 \times 12=12.000 \\
-1.000 \times 12=12.000 \\
-1.000 \times 12=12.000 \\
=72.000 \\
=130.800-72.000=58.800 \\
\text { Zakat }=2,5 \% \times 58.800=1.470\end{array}$ & \begin{tabular}{lr}
\multicolumn{2}{l}{ Penghasilan } \\
bersih di atas \\
nisab emas, \\
maka & wajib \\
kena & zakat \\
sebesar & Rp. \\
1.470 .000 & per \\
tahun atau & Rp. \\
122.500 & per \\
bulan &
\end{tabular} \\
\hline 3 & $\begin{array}{l}\text { Pendapatan: } \\
\text { - Gaji Pokok dan Tunjangan } \\
\quad \text { tanpa tambahan gaji } \\
\text { istri/suami } \\
\text { Total Pendapatan } \\
\text { Pengeluaran kebutuhan pokok } \\
\text { - Konsumsi } \\
\text { - Listrik, Air dan Telpon } \\
\text { - } \quad \text { Transportasi } \\
\text { - Pendidikan } \\
\text { Total Pengeluaran } \\
\text { Penghasilan Bersih } \\
\end{array}$ & $\begin{array}{l}-10.000 \times 12=120.000 \\
=120.000 \\
-1.000 \times 12=12.000 \\
-1.000 \times 12=12.000 \\
-1.000 \times 12=12.000 \\
=72.000 \\
=120.000-72.000=48.000 \\
\text { Zakat }=2,5 \% \times 48.000=1.200\end{array}$ & $\begin{array}{l}\text { Penghasilan } \\
\text { bersih di atas } \\
\text { nisab emas, } \\
\text { maka wajib } \\
\text { kena zakat } \\
\text { sebesar Rp. } \\
\begin{array}{ll}1.200 .000 \text { per } \\
\text { tahun atau }\end{array} \\
\begin{array}{ll}100.000 \\
\text { bulan }\end{array}\end{array}$ \\
\hline
\end{tabular}

Sumber: Data diolah tahun 2018

Berdasarkan pada skenario perhitungan zakat di atas, maka dapat diketahui bahwa responden yang berada pada skenario satu tidak kena wajib zakat 
meskipun ada tambahan penghasilan dari suami atau istri. Pada skenario dua, penghasilan kena zakat jika penghasilan suami dan istri di atas 5 juta. Pada skenario dua ini, maka ada 46,5 persen responden menjadi wajib zakat, karena memiliki penghasilan bersih tahunan di atas nisab emas. Pada skenario ketiga, diasumsikan jika penghasilan keluarga hanya bersumber dari suami atau istri saja, maka penghasilan minimal adalah 10 juta. Pada skenario ketiga ini, hanya ada 7,5 persen responden yang kena wajib zakat. Perhitungan di atas menggunakan asumsi semua jenis pengeluaran menjadi kebutuhan pokok.

\subsection{Analisis Peluang dan Tantangan}

Sebanyak 83 persen responden memberika respon positif terkait dengan pungutan zakat atas gaji Pegawai Negeri. Hal ini menunjukkan akan kesadaran atas kewajiban umat Islam untuk mengeluarkan hartanya dalam bentuk zakat. respon ini menjadi kekuatan bagi pemerintah untuk melakukan pungutan zakat penghasilan bagi pegawai negeri yang beragama Islam. Untuk mendukung terlaksananya pungutan zakat yang profesional, maka pemerintah menerbitkan UU No 38 tahun 1999 tentang Pengelolaan Zakat dan digantikan dengan UU No 23 tahun 2011 tentang Pengelolaan Zakat. Undang-undang ini menjadi dasar hukum bagi pemerintah untuk menarik zakat penghasilan profesi terutama bagi pegawai negeri. Dalam undang-undang tersebut dijelaskan bahwa zakat yang telah dibayarkan melalui Badan Amil Zakat resmi akan mengurangkan penghasilan kena pajak.

Sementara itu, hambatan pemerintah untuk menerapkan kebijakan ini adalah tidak semua Pegawai Negeri beragama Islam, sehingga memerlukan pemetaan secara menyeluruh atas profil pegawai. Agar tidak muncul kesenjangan antara pegawai muslim dan non-muslim terkait dengan sejumlah pemotongan atas gaji mereka. Di samping itu, hambatan lain yang muncul adalah informasi terkait dengan pengeluaran kebutuhan pokok pegawai yang berbeda-beda. Bahkan kebutuhan dasar hidup layak antar daerah sangat bervariasi sehingga akan berpengaruh terhadap pengeluaran pegawai. Di sisi lain, inflasi yang tinggi juga akan menambah beban bagi pegawai negeri.

Hambatan lainnya adalah sistem pungutan zakat dan pajak yang harus terintegrasi, sehingga pungutan langsung zakat atas gaji pegawai dapat sejalan dengan pemotongan pajak. UU No 23 tahun 2011 tentang Pengelolaan Zakat tersebut hanya mengakomodir pembayar zakat di Lembaga Amil Zakat, sehingga seorang Pegawai Negeri (muzakki) harus menyerahkan bukti pembayaran zakat kepada pemerintah untuk mendapatkan bukti pengurangan penghasilan kena pajak.

\section{Kesimpulan}

Berdasarkan pada pembahasan di atas, maka ada dua kesimpulan yang dapat diambil terkait dengan kebijakan pemotongan zakat gaji pegawai negeri adalah: Pertama, pungutan langsung atas gaji tanpa pertimbangan pengeluaran kebutuhan pokok. Pungutan ini dapat menggunakan standar nisab zakat pertanian ataupun emas. Kelebihan metode ini adalah kemudahan dalam pemotongan gaji tanpa 
perlu informasi pengeluaran kebutuhan pokok hidup masing-masing pegawai yang mencapai jutaan pegawai. Kelemahan metode ini adalah meningkatnya beban pegawai. Solusinya adalah pemberian subsidi atau peningkatan pendapatan berbasis kinerja.

Kedua, pungutan zakat atas penghasilan bersih setelah pengurangan pengeluaran kebutuhan pokok dan dilaksanakan pada akhir tahun dengan pertimbangan perhitungan total penghasilan dari berbagai sumber, seperti penghasilan di luar pekerjaan, penghasilan suami atau istri. Kelebihan metode ini adalah zakat yang dibayarkan adalah merupakan kelebihan harta (bersih) sehingga tidak menjadi beban bagi pegawai. kelemahannya adalah perlunya pengawasan yang ketat terhadap jenis-jenis biaya kebutuhan pokok, jumlah biaya maksimal untuk setiap jenis biaya. Pertimbangan penentuan jenis cicilan hutang seperti hutang cicilan kendaraan roda empat yang seharusnya termasuk barang mewah. Penentuan jenis hutang ini penting dilakukan mengingat hutang merupakan salah satu pengurang harta kena wajib zakat.

\section{Daftar Pustaka}

Afriyandi, Y., 2014. Sinergitas Pajak Dan Zakat Dalam Keuangan Publik Islam. Rasail.

Ash-Shawi, S., Al-Muslih, A., 2008. Fikih Ekonomi Keuangan Islam. Darul Haq, Jakarta.

Erni, S., 2016. Sustainable Life Style Masyarakat Perkotaan ( Studi Tentang Gaya Hidup Berkelanjutan Masyarakat Perkotaan di Riau ). SOROT 11, 75-86.

Hayeeharasah, F., Sehvises, S., Ropha, H., 2013. The Timeline of Zakah. Procedia - Soc. Behav. Sci. 88, 2-7. https://doi.org/10.1016/j.sbspro.2013.08.474

Huda, N., Gofur, A., 2012. Analisis Intensi Muzakki Dalam Membayar Zakat Profesi. Al-Iqtishad 4.

Kumpulan Berita Resmi Statistik Provinsi Sumatera Selatan 2017, 2017.

Kurnia, H., Ade Hidayat, 2008. Panduan Pintar Zakat. QultumMedia, Jakarta Selatan.

Marimin, A., Tira Nur Fitria, 2015. Zakat Profesi (Zakat Penghasilan) Menurut Hukum Islam. J. Ilm. Ekon. Islam 1, 50-60.

Mufidah, N.L., 2006. Pola Konsumsi Masyarakat Perkotaan: Studi Deskriptif Pemanfaatan Foodcourt oleh Keluarga. Biokultur 157-178.

Nurhayati, S., Wasilah, 2013. Akuntansi Syariah di Indonesia. Salemba Empat, Jakarta.

Qardhawi, Y., 1999. Hukum Zakat. Penerbit Litera AntarNusa dan Mizan.

Riyadi, F., 2015. Kontroversi Zakat Profesi Pesrpektif Ulama Kontemporer. ZIWAF 2, 110-132. 
Saad, R.A.J., Aziz, N.M.A., Sawandi, N., 2014. Islamic Accountability Framework in the Zakat Funds Management. Procedia - Soc. Behav. Sci. 164, 508-515. https://doi.org/10.1016/j.sbspro.2014.11.139

Saad, R. al J., Haniffa, R., 2014. Determinants of zakah (Islamic tax) compliance behavior. J. Islam. Account. Bus. Res. 5, 158-181.

Zen, M., 2014. Zakat Profesi Sebagai Distribusi Pendapatan Ekonomi Islam. Hum. FALAH 1, 63-91.

Sumber Media Masa Online

Alasan Pemerintah Pungut Langsung Zakat PNS Muslim, 2018. republika.co.id. https://doi.org/http://nasional.republika.co.id/berita/nasional/newsanalysis/18/02/08/p3t4ig415-ini-alasan-pemerintah-pungut-langsung-zakatgaji-pns-muslim

Alex Noerdin Tetapkan UMP Sumsel 2018 Sebesar Rp2.595.994, 2017. sindonews.com.

https://doi.org/https://daerah.sindonews.com/read/1253632/190/alex-noerdintetapkan-ump-sumsel-2018-sebesar-rp2595994-1509541149

Baznas Dukung Sri Mulyani untuk Kelola Zakat Seperti Pajak, 2017. Republika.co.id.

https://doi.org/http://www.republika.co.id/berita/ekonomi/makro/17/08/25/ov 8tnd382-baznas-dukung-sri-mulyani-untuk-kelola-zakat-seperti-pajak

Berapa Besar UMR Kota Palembang?, 2017. tribunews.com. https://doi.org/http://palembang.tribunnews.com/2017/12/09/berapa-besarumr-kota-palembang

MUI Dukung Rencana Pemotongan Gaji PNS untuk Zakat, 2018. tempo.co. https://doi.org/https://nasional.tempo.co/read/1057849/mui-dukung-rencanapemotongan-gaji-pns-untuk-zakat

Nurhayati, S., Wasilah, 2013. Akuntansi Syariah di Indonesia. Salemba Empat, Jakarta.

Ombudsman: Pungutan Zakat PNS Muslim Berpotensi Maladministrasi, 2018. https://doi.org/https://nasional.tempo.co/read/1058086/ombudsmanpungutan-zakat-pns-muslim-berpotensi-maladministrasi

Sri Mulyani Ingin Zakat Dikelola seperti Pajak, 2017. liputan6.com. https://doi.org/http://bisnis.liputan6.com/read/3068350/sri-mulyani-inginzakat-dikelola-seperti-pajak 